\title{
A proteomic view of Caenorhabditis elegans caused by short-term hypoxic stress
}

\author{
Hualing $\mathrm{Li}^{1,2,3+}$, Changhong Ren ${ }^{2+}$, Jinping Shi ${ }^{2+}$, Xingyi Hang ${ }^{2}$, Feilong Zhang ${ }^{2}$, Yan Gao ${ }^{2}$, Yonghong Wu ${ }^{2}$, \\ Langlai $\mathrm{Xu}^{1^{*}}$, Changsheng Chen ${ }^{4^{*}}$, Chenggang Zhang ${ }^{2^{*}}$
}

\begin{abstract}
Background: The nematode Caenorhabditis elegans is both sensitive and tolerant to hypoxic stress, particularly when the evolutionarily conserved hypoxia response pathway HIF-1/EGL-9/NHL is involved. Hypoxia-induced changes in the expression of a number of genes have been analyzed using whole genome microarrays in C. elegans, but the changes at the protein level in response to hypoxic stress still remain unclear.
\end{abstract}

Results: Here, we utilized a quantitative proteomic approach to evaluate changes in the expression patterns of proteins during the early response to hypoxia in C. elegans. Two-dimensional difference gel electrophoresis (2D-DIGE) was used to compare the proteomic maps of wild type C. elegans strain N2 under a 4-h hypoxia treatment $(0.2 \%$ oxygen) and under normoxia (control). A subsequent analysis by MALDI-TOF-TOF-MS revealed nineteen protein spots that were differentially expressed. Nine of the protein spots were significantly upregulated, and ten were downregulated upon hypoxic stress. Three of the upregulated proteins were involved in cytoskeletal function (LEV-11, MLC-1, ACT-4), while another three upregulated (ATP-2, ATP-5, VHA-8) were ATP synthases functionally related to energy metabolism. Four ribosomal proteins (RPL-7, RPL-8, RPL-21, RPS-8) were downregulated, indicating a decrease in the level of protein translation upon hypoxic stress. The overexpression of tropomyosin (LEV-11) was further validated by Western blot. In addition, the mutant strain of lev-11(x12) also showed a hypoxia-sensitive phenotype in subsequent analyses, confirming the proteomic findings.

Conclusions: Taken together, our data suggest that altered protein expression, structural protein remodeling, and the reduction of translation might play important roles in the early response to oxygen deprivation in C. elegans, and this information will help broaden our knowledge on the mechanism of hypoxia response.

\section{Background}

Hypoxic stress can induce apoptosis but also trigger adaptive mechanisms for cell survival. Mammalian cells respond to hypoxia by changes in the expression of numerous genes and proteins to increase anaerobic energy production, protect cells from hypoxic stress, and increase local angiogenesis [1,2]. Recently, the nematode Caenorhabditis elegans (C. elegans) has been proven to be an valuable model organism for studying the molecular response to hypoxia $[3,4]$. Although C. elegans is

\footnotetext{
* Correspondence: xulanglai@njau.edu.cn; chencs@fmmu.edu.cn; zhangcg@bmi.ac.cn

† Contributed equally

'Life Science College of Nanjing Agriculture University, Nanjing 210095,

China

${ }^{2}$ Beijing Institute of Radiation Medicine, State Key Laboratory of Proteomics, Beijing 100850, China

Full list of author information is available at the end of the article
}

sensitive to hypoxic stress, resulting in a phenotype characterized by decreased levels of feeding, movement, and oxygen consumption, it can also survive oxygen tensions between $1 \%$ and $0.2 \%$ by activating the hypoxia response pathway or anoxic conditions by entering suspended animation. Worms at all stages of development can survive at least one day of anoxia with a viability of 90\% [5-7], and C. elegans is relatively hypoxia-resistant compared to most mammalian cells $[7,8]$. Powell Coffman et al. reported that the $C$. elegans homolog of the HIF-1 (hypoxia induced factor- 1 ) $\alpha$ subunit is hif- 1 and that the HIF-1/EGL-9/VHL pathway is evolutionarily conserved [9]. The most surprising finding was the first globin gene in the genome of $C$. elegans since these small worms were generally thought to rely on diffusion from the environment for gaseous exchange due to their lack of a specialized respiratory or circulatory system $[10,11]$.
C Biomed Central

() 2010 Li et al; licensee BioMed Central Ltd. This is an Open Access article distributed under the terms of the Creative Commons Attribution License (http://creativecommons.org/licenses/by/2.0), which permits unrestricted use, distribution, and reproduction in any medium, provided the original work is properly cited. 
Recently, Hoogewijs et al. identified 33 putative globin genes by a careful in silico analysis of the genome of C. elegans $[12,13]$. All of these globins are expressed, and they show a wide diversity in their gene structures and amino acid sequences. Ten globins are responsive to oxygen deprivation through interactions with HIF-1 and DAF-16. The explanations for the large number of globins and their functions in this tiny worm remain a mystery. In addition, the determinants of the hypoxia response and survival in $C$. elegans are still not completely understood. Therefore, these mechanisms should be studied to gain more knowledge on oxygen-deprivation sensing and survival in C. elegans.

The response of $C$. elegans to hypoxia, including its behavioral and physiological issues, has been well studied [14-16]. More recently, genomics studies have identified a comprehensive set of hypoxia response genes in C. elegans [17-19]. For example, Shen et al. compared hypoxiainduced changes in mRNA expression in wild type, hif-1deficient, and $v h l$-1-deficient $C$. elegans strains using whole genome microarrays [20], which resulted in the identification of 110 hypoxia-regulated gene expression changes after $4 \mathrm{~h}$ under hypoxia. Because the expression of the proteins are directly related to cellular functions [21], other reports have examined the proteome-wide alterations during hypoxia in mammalian cells [22,23], zebrafish [24], rainbow trout [25], shrimp [26] and others. As frequently mentioned, analysis of gross proteomic changes, which would complement the available mRNA data, might be necessary to achieve a better insight into the hypoxia response. A proteomic study on hypoxia in C. elegans, however, has not yet been performed.

In C. elegans, proteomic approaches are becoming part of the essential toolbox for the study of gene function [27]. For example, these studies have been applied to the investigation of differentially expressed proteins during postembryonic development [28] or when living at different temperatures [29]. Mawuenyega et al. also analyzed the worm proteome by 2D gel electrophoresis liquid chromatography (2D-LC) combined with electrospray ionization tandem mass spectrometry (ESI-MS/ MS) and identified a total of 1,616 proteins, including 110 secreted/targeted proteins and 242 transmembrane proteins [30]. Quantitative proteomics can efficiently provide accurate and reproducible differential expression values for proteins [31,32]. Two-dimensional difference gel electrophoresis (2D-DIGE) has been successfully used for the proteomic analysis of various biological and medical subjects, such as the identification of differentially expressed proteins in Escherichia coli [33], Saccharomyces cerevisiae [34], mouse [35] and human hepatocellular carcinoma [36]. Using 2D-DIGE, Tabuse et al. compared the proteome maps from all six developmental stages, embryonic, L1-L4 larva1, and adult, to examine the expression profiles of 165 proteins during C. elegans development [37].

To better understand the molecular mechanisms underlying the response to hypoxic stress at the protein level in C. elegans, a 2D-DIGE and mass spectrometry (MS) based approach was used to determine the overall profile of protein expression during the early response to hypoxia. Differentially expressed protein spots were identified, and the proteins of interest were validated by Western blot. Further study of one of the hypoxia-induced proteins expressed at a high level was performed by using a mutant strain obtained from the Caenorhabditis Genetics Center (CGC). Consistent with our proteomic findings, the lev-11(x12) mutant strain had a higher death rate than the wild type strain N2 under hypoxic stress. To the best of our knowledge, this study is the first to apply a proteomic approach to screen differentially expressed proteins in response to hypoxia in C. elegans, and the results may provide new clues to understand the mechanism of hypoxia response better.

\section{Results}

\section{D-DIGE-based proteomic analysis}

To determine the proteins that were differentially expressed proteins during the early stage of the hypoxia response, a proteomic study using 2D-DIGE followed by MALDI-TOF-TOF-MS was performed on the wild type strain N2 of C. elegans under hypoxia or normoxia (control) for $4 \mathrm{~h}$. The labeled samples were separated, and the fluorescent images were obtained (Figure 1). The lysate extracted from the hypoxia and control groups were labeled with either Cy5 (Figure 1, top panel) or Cy3 (Figure 1, bottom panel) to enable all comparisons and eliminate any dye-labeling bias, while equal amounts of protein from the sample pairs were pooled together as an internal standard and labeled with Cy2. The normalized ratio of the protein expression level for each spot was calculated relative to the internal standard, and inter-gel spot matching was performed using the DeCyder software. The incorporation of this internal standard on each gel has been reported to improve the accuracy of spot matching and the reliability of the quantitative comparison of the spots between gels [32]. Therefore, this method was sufficient to enable us running two DIGE-gels at the same time. Bioinformatic analyses of the images detected approximately 1,308 significantly altered spots in GEL1, 1,307 spots in GEL2, and a total of 1,231 spots in both gels. The matching ratio of the protein spots between the two gels was approximately $94.1 \%$, indicating that DIGEbased proteomic analysis is an appropriate method to study hypoxia in C. elegans. Many of the protein spots are similar between the two experimental conditions, 


\section{Gel1: Cy3}

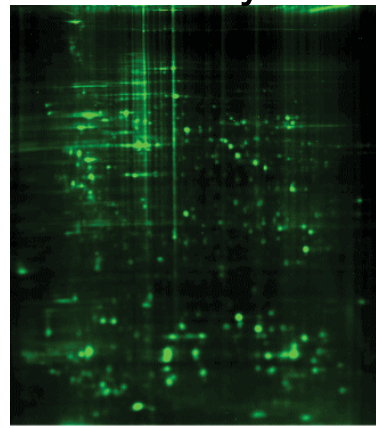

Gel2: Сy3

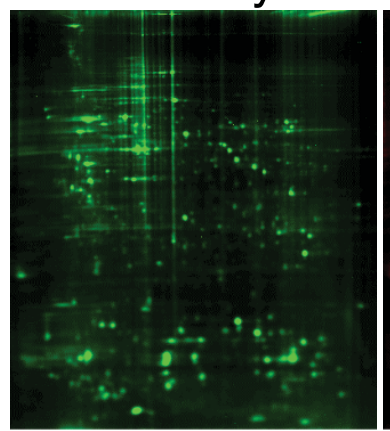

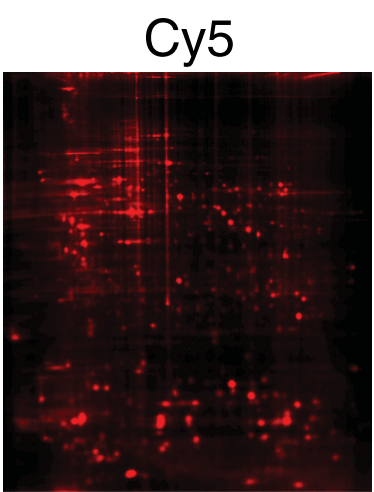
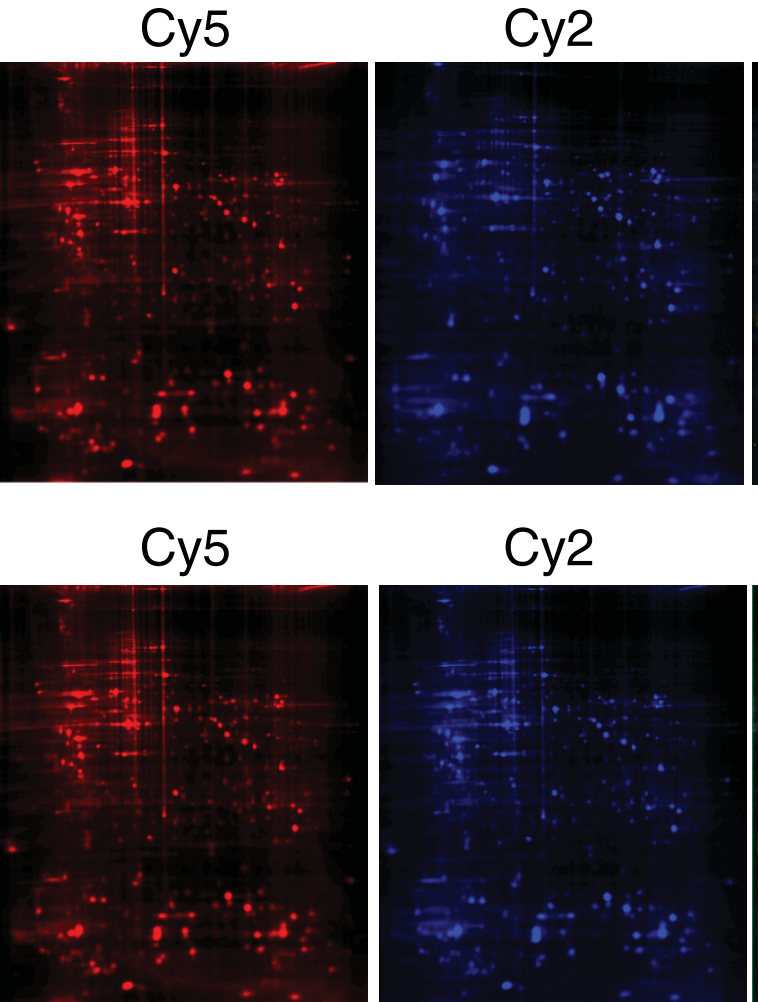

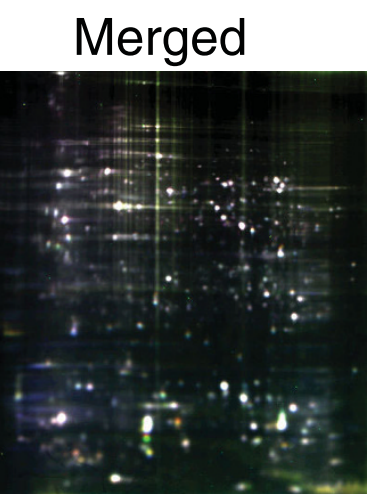

Merged

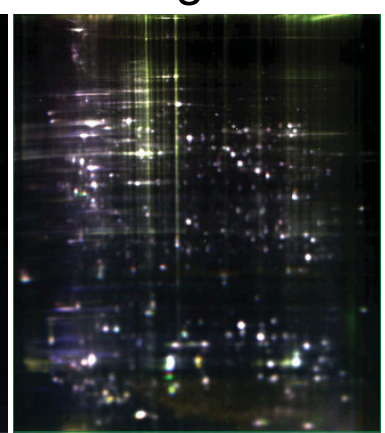

Figure 1 DIGE maps of the C. elegans wild type (N2) after $\mathbf{4}$ h hypoxia. In GEL1 (top panel), the control lysate was labeled with Cy3 (green) and the lysate from $4 \mathrm{~h}$ hypoxia group was labeled with Cy5 (red). In GEL2 (bottom panel), reverse labeling was used so that the control was labeled with Cy5 (red) and the hypoxia group was labeled with Cy3 (green). For normalization in both gels, a mixture containing equal parts of the control and hypoxia groups was labeled with Cy2 (blue). The three Cy-dye labeled samples were co-separated on one gel, and the merged gel was created by the overlay of the three images. In total, 1,231 spots were matched from each of the fluorescent gels.

likely representing a L4-stage wild type strain-related proteomic profile.

\section{Identification of differentially expressed proteins}

Among the 1,231 matched protein spots that satisfied the arbitrary parameters defined as the relative expression ratio hypoxia/control $\geq 1.5$ for upregulated spots and $\leq-1.5$ for downregulated spots, 23 protein spots displaying significant changes $(P<0.05)$ were selected (Figure 2$)$. Each spot of interest was excised from preparative gel and analyzed by MALDI-TOF/TOF-MS after in-gel tryptic digestion. The combined spectra were searched against the Swiss-Prot database of C. elegans using a Mascot engine, which resulted in the successful identification of nineteen spots. The protein name, accession number, theoretical molecular weight, $P$ value and $p I$ values, spot number and score are shown in Table 1. Under hypoxia, nine of these proteins were significantly upregulated, and ten were downregulated. These data represent the first description of the regulatory expression profiles of C. elegans during early hypoxia. The upregulated proteins were associated with structural proteins, ATP synthesis and energy metabolism, whereas the downregulated proteins were mainly associated with ribosomal proteins.

\section{Confirmation of protein expression by Western blot}

To evaluate the performance of the quantitative proteomic approach used in this study, the worm protein tropomyosin (LEV-11), identified as the most highly induced protein by hypoxia, was further examined by Western blot. Tropomyosin (LEV-11) was significantly upregulated in the 4-h hypoxia treatment samples when compared with the controls $(P=0.0069$, Figure 3$)$. The agreement between the 2D-DIGE and Western blot results basically validates this proteomic approach.

\section{Hypoxia-induced death rates of the tropomyosin gene mutant strain lev-11(x12) and wild type C. elegans}

To determine the function of tropomyosin (LEV-11), the survival ability of the L4 stage of the wild type and the mutants lev-11(x12), daf-2 (hypoxia-resistant), and daf16 (hypoxia-sensitive) were examined under hypoxic conditions $\left(26^{\circ} \mathrm{C}, 0.2 \% \mathrm{O}_{2}\right)$. The death rate of the wild type $\mathrm{N} 2$ strain and $l e v-11(x 12)$ mutant gradually increased as 

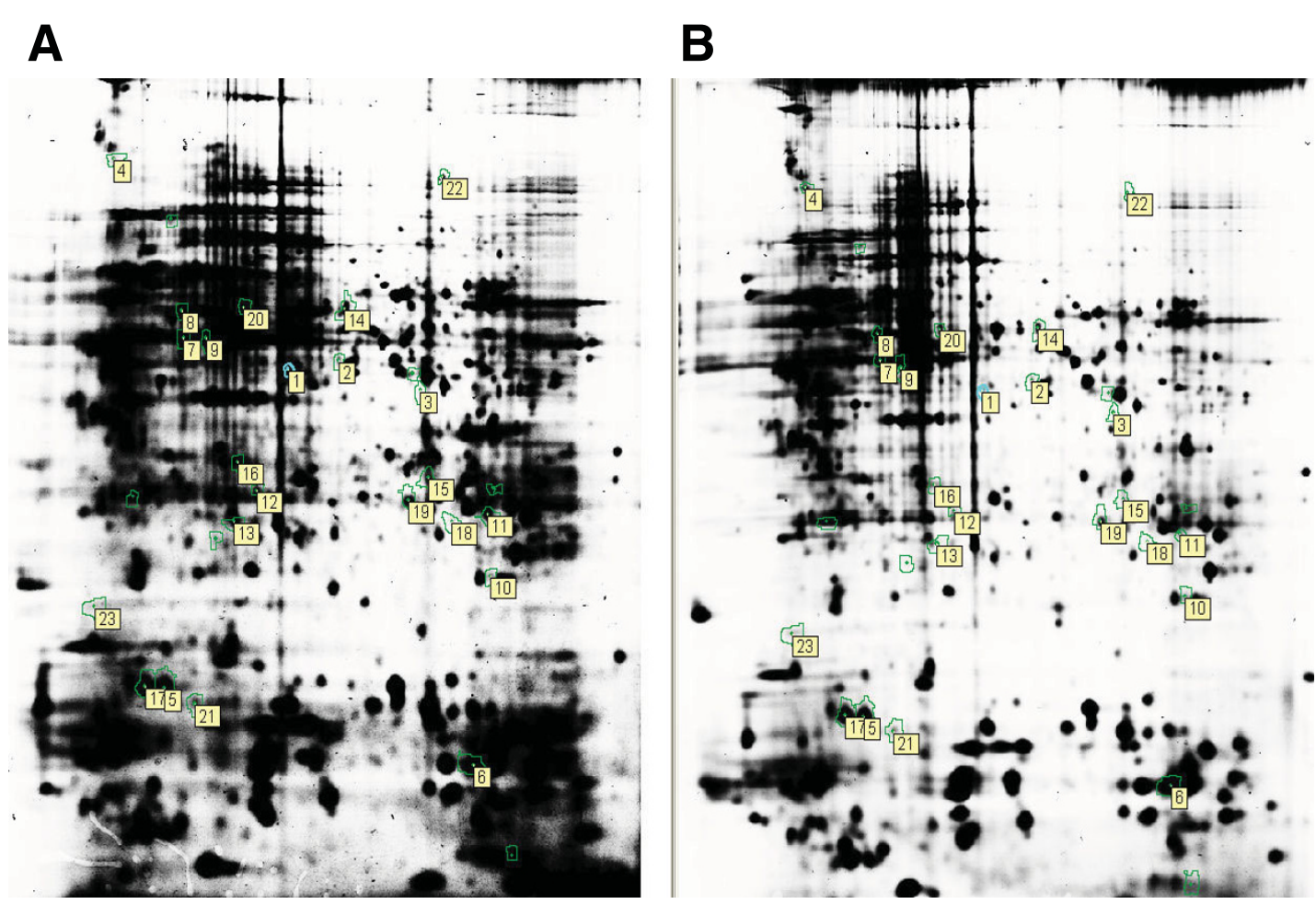

Figure 2 The 2D-DIGE protein map. The number and positions of 23 selected spots (ratio hypoxia/control $\geq 1.5$ for upregulated spots and $\leq-1.5$ for downregulated spots, $P<0.05$ ) labeled from 1 to 23 within the brackets for identification by MALDI-TOF/TOF-MS are shown. (A) control; (B) $4 \mathrm{~h}$ hypoxia. A total of 19 proteins were successfully identified.

the time under hypoxic conditions increased as well as after a 24-h recovery (Figure 4). The daf-2 mutants were highly resistant to hypoxia, while the daf-16 mutants were highly sensitive to hypoxia. The death rate was significantly different when the wild type animals $(8.85 \% \pm$ $3.50,26.44 \% \pm 7.96, \mathrm{n}>3$ ) were compared with the lev11 (x12) strain $(27.64 \% \pm 6.30,64.06 \% \pm 12.00, \mathrm{n}>3)$ after $12 \mathrm{~h}$ and $14 \mathrm{~h}$ of hypoxia treatment $(P=0.0183, P=$ $0.0401)$, respectively. When compared with the wild type worms, the lev-11 (x12) mutants have a higher death rate and are more sensitive to oxygen deprivation. After $12 \mathrm{~h}$ of hypoxia, the death rate of the lev-11 (x12) strain was higher than that of the daf-16 mutant. These data further support the proteomic data presented here and suggest that the protein tropomyosin (LEV-11) has an important role in the early hypoxia response and survival for $C$. elegans.

\section{GO analysis}

A gene ontology (GO) classification was performed to analyze the distribution of the differentially expressed proteins identified in this study within the different biological process categories (Table 2). The largest protein set belongs to the functional group of proteins involved in larval development $(P=6.54 \mathrm{E}-06)$. Other proteins are involved in the positive regulation of growth, ATP metabolic process, purine ribonucleotide binding, hydrogen transport, and proton transport, with significant $P$-values. These biological processes are all consistent with changes made in response to stress conditions. These classifications provide clues to understand better the proteomic expression changes in the nematode in vivo during the early response to hypoxia.

\section{Discussion}

C. elegans is a model organism for research in the fields of developmental biology, molecular biology, neurobiology and toxicology [38-40]. Here, we showed that C. elegans can also be used as a model organism for hypoxia studies. Using 2D-DIGE followed by protein identification through mass spectroscopy, nineteen proteins that responded during the early stage of hypoxia exposure were successfully identified. Although only a small number of proteins was identified, a precise evaluation of the results presented here still needs to be performed.

It is especially important for using the proteomic approach to determine the differently expressed protein spots from multiple independent experiments. Here we ran three gels for each DIGE analysis on one batch of C. elegans, and we totally used three batches of 
Table 1 List of differently expressed proteins in C. elegans wild type strain N2 with hypoxia treatment for 4 h

\begin{tabular}{|c|c|c|c|c|c|c|}
\hline $\begin{array}{l}\text { Spot } \\
\text { No. }\end{array}$ & Protein name & Score & $\begin{array}{l}\text { Accession } \\
\text { number }\end{array}$ & $\begin{array}{l}\text { Theoretical mass } \\
(\mathrm{Da})\end{array}$ & $\begin{array}{l}\text { Theoretical } \\
\text { pl }\end{array}$ & $\begin{array}{c}P \\
\text { value }\end{array}$ \\
\hline \multicolumn{7}{|c|}{ Up-regulated proteins (totally 9) } \\
\hline 1 & Isoform a of tropomyosin isoforms a/b/d/f. lev-11 & 94 & Q22866-1 & 32984 & 4.66 & 0.037 \\
\hline 2 & Protein F27D4.5, confirmed by transcript evidence.tag- 173 & 177 & Q93619 & 40027 & 6.22 & 0.028 \\
\hline 3 & Isoform a of probable arginine kinase. F46H5.3 & 152 & Q10454-1 & 44140 & 6.84 & 0.002 \\
\hline 5 & Myosin regulatory light chain $1 . \mathrm{mlc}-1$ & 496 & P19625 & 18605 & 5.06 & 0.004 \\
\hline 6 & Fatty-acid and retinol-binding protein 1.far-1 & 528 & P34382 & 20097 & 6.98 & 0.031 \\
\hline 7 & Actin protein 4 , isoform c. act-4 & 530 & Q6A8K1 & 40400 & 5.56 & 0.021 \\
\hline 8 & ATP synthase subunit beta, mitochondrial. atp-2 & 401 & P46561 & 57491 & 5.52 & 0.045 \\
\hline 10 & Protein $\mathrm{C} 06 \mathrm{H} 2.1$, confirmed by transcript evidence.atp- 5 & 245 & Q17763 & 21784 & 6.67 & 0.042 \\
\hline 11 & Vacuolar h Atpase protein 8.vha-8 & 153 & Q95X44 & 25570 & 6.78 & 0.048 \\
\hline \multicolumn{7}{|c|}{ Down-regulated proteins (totally 10 ) } \\
\hline 12 & $\begin{array}{l}\text { Protein ZK593.9, partially confirmed by transcript } \\
\text { evidence }\end{array}$ & 66 & Q23538 & 595560 & 9.07 & 0.032 \\
\hline 13 & Isoform b of probable arginine kinase. $\mathrm{F} 46 \mathrm{H} 5.3$ & 83 & Q10454-2 & 39966 & 6.17 & 0.017 \\
\hline 14 & Isoform a of muscle M-line assembly protein. unc- 89 & 60 & O01761-2 & 731233 & 5.35 & 0.001 \\
\hline 15 & 605 ribosomal protein L7. rpl-7 & 80 & 001802 & 28114 & 10.16 & 0.022 \\
\hline 16 & 605 ribosomal protein L8. rpl-8 & 72 & Q9XVF7 & 28186 & 11.07 & 0.040 \\
\hline 17 & Myosin regulatory light chain 2 . mlc-2 & 493 & P19626 & 18591 & 5.06 & 0.034 \\
\hline 18 & 40 S ribosomal protein S8. rps-8 & 133 & P48156 & 23736 & 10.56 & 0.027 \\
\hline 19 & Heat shock 70 kDa protein A. hsp-1 & 95 & P09446 & 69680 & 5.44 & 0.034 \\
\hline 21 & Protein Y54E5A.5, confirmed by transcript evidence & 152 & Q9XWK2 & 17426 & 5.24 & 0.030 \\
\hline 23 & 60S ribosomal protein L21. rpl-21 & 232 & P34334 & 18299 & 11.15 & 0.027 \\
\hline
\end{tabular}

C. elegans as independent experiments to meet the standard for biological replicates. In addition, the quantitative proteomic method, DIGE, was used in this study. Briefly, samples were reverse-labeled (cy3 or cy5) to enable all comparisons and eliminate any dye-labeling bias. Samples were also mixed together and run on the same gels with an equal amount of the cy2-labeled standard. Cy2 was used as a standard on all gels to aid image matching and cross-gel statistical analyses. The use of this internal standard in all 2-DE gels greatly improved the accuracy of spot matching and the reliability of protein quantification. Therefore, this method was sufficient to enable us running two DIGE-gels at the same time, and the Decyder software was used to analyze the data. Protein spots that were differentially expressed in hypoxia-treated and control groups (ratio: hypoxia/control $\geq 1.5$ or hypoxia/control $\leq-1.5, P<$ $0.05)$ were marked. Protein samples were extracted from the nematodes at least eight times, and the extracted were mixed together. All these operations are important to improve the fidelity of the protein spots identified in this study.

Structural proteins involved in cytoskeletal organization Proteins contained several structural proteins, including actin (ACT-4), the myosin regulatory light chain (MLC) and tropomyosin (LEV-11), were upregulated during early hypoxic stress in the L4 stage. These proteins are typical structural proteins that are ubiquitously expressed in all eukaryotic cells and that play essential roles in myofibril assembly and muscle contraction. C. elegans has only two main muscle tissues, which are the body wall for locomotion and the pharynx for feeding. The actin cytoskeleton is important for many cellular functions, including cell motility, structure and integrity. C. elegans has four actin genes that are highly homologous [41]. Isoforms $\mathrm{d}$ (act-4) and b (act-2) have the most similar amino acid sequences. In our study, actin isoform d was upregulated after hypoxic stress. Homologs of the actin isoform b were upregulated after long-term anoxia in the rainbow trout hypodermal fibroblast cell-line [25] and after a oneto two-week exposure to hypoxia in the pulmonary arterial smooth muscle cells of rats [42]. In human umbilical vein endothelial cells at lower oxygen concentrations [43], however, actin isoform b was downregulated. These contrasting responses of actin to hypoxia might be the result of different stages and experimental conditions as well as suggest that the actin isoforms might have different roles in the response to hypoxic stress in different organisms.

Mlc-1 and Mlc-2 both encode a muscle regulatory myosin light chain that is involved in L1 larval viability, elongation, muscle development of the pharynx and body 

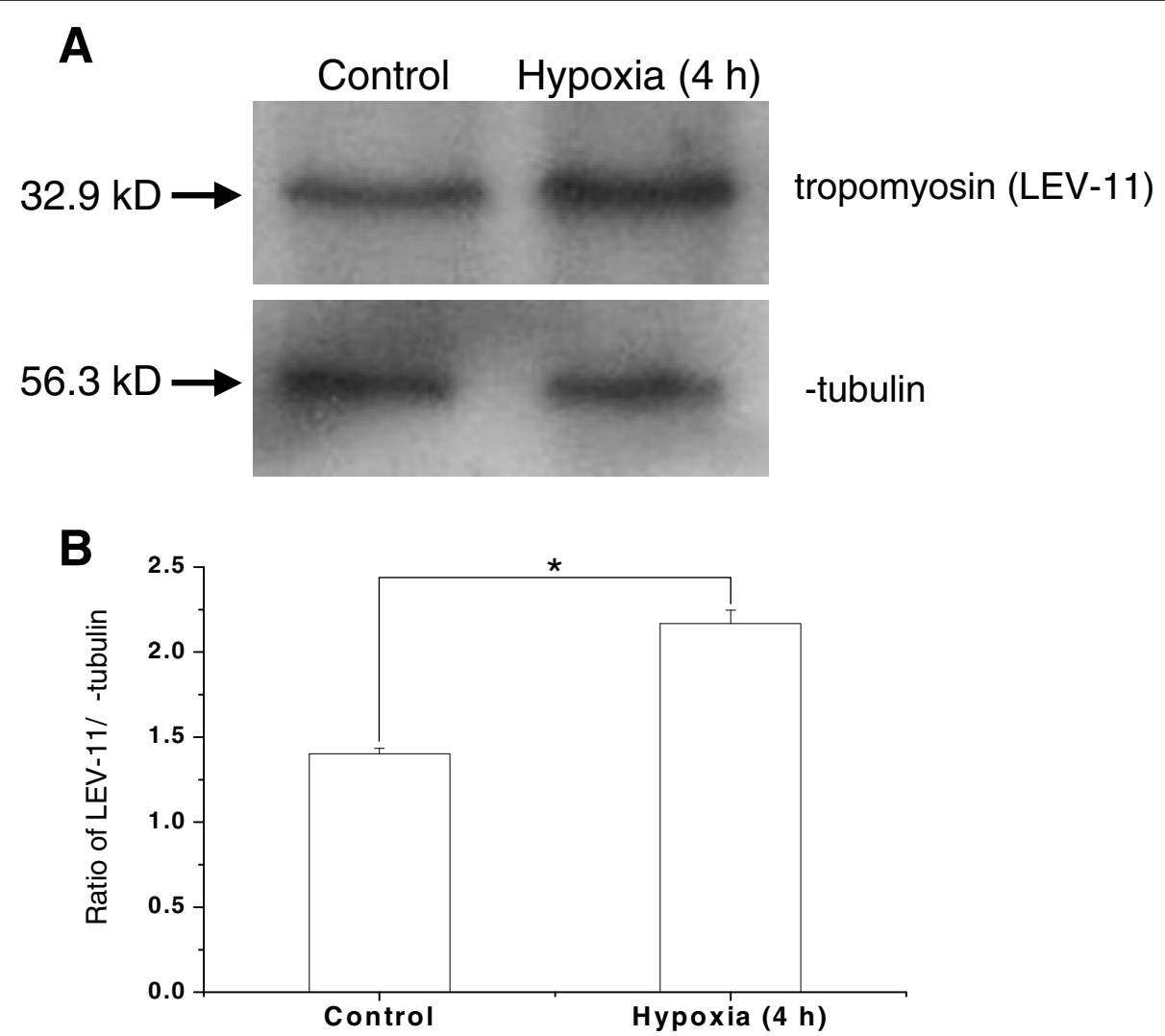

Figure 3 Validation of the upregulation of the tropomyosin ( $32.9 \mathrm{kDa})$ protein in wild type $\mathrm{N} 2$ after $4 \mathrm{~h}$ hypoxia treatment. (A) Western blot analysis showing the upregulation of tropomyosin protein in wild type $\mathrm{N} 2$ after $4 \mathrm{~h}$ hypoxia treatment compared with the control. The protein $\alpha$-tubulin $(56.3 \mathrm{kDa}$ ) was used as an internal control. (B) Image analysis showing that the expression of tropomyosin (LEV-11) is significantly upregulated at $4 \mathrm{~h}$ hypoxia compared with the control $(P=0.0069)$. The expression pattern of LEV-11 was consistent with the quantitative proteomic results.

wall, locomotion and growth [44]. The role of MLC in the regulation of muscle cell contraction is well characterized [45], but its function during hypoxic stress is not completely understood. In the current study, hypoxia induced the synthesis of MLC-1 but decreased the amount of MLC-2. MLC-1 and MLC-2 are nearly identical with the exception of a single conservative amino acid substitution [44]. This difference in gene structure might reflect the differences in their expression patterns.

Unc-89 encodes isoform a of the muscle M-line assembly protein. UNC-89 is required for the proper organization of A bands in striated muscle and thus for normal locomotion, pharyngeal muscle contraction, and body size [46]. UNC-89 was downregulated under these hypoxic conditions, which suggests that the striated muscle structure becomes disorganized after hypoxia treatment. This notion needs to be further studied.

Interestingly, the most highly upregulated protein was tropomyosin, which was confirmed by western blot. The protein LEV-11 (spot \#1) is a major component of the contractile apparatus of the muscle cells that maintain cell cytoarchitecture. LEV-11 is associated with the actin thin filament and plays a regulatory role in the organization of actin microfilaments and stress fibers. LEV-11 transmits structural changes along the thin filament during the regulatory process. The effect of increased calcium levels could be transferred to actin molecules $[47,48]$. The increased synthesis of tropomyosin allows C. elegans to maintain its shape and cell adherence. The hypoxia-induced synthesis of tropomyosin has also been reported in pulmonary arterial myocytes [49], Which is consistent with our data. Lev-11 is orthologous to human tropomyosin 1 (TPM1), in which mutations lead to familial hypertrophic cardiomyopathy [50]. C. elegans with the lev-11 gene mutant were paralyzed together with abnormal muscle filament assembly [51]. To further analyze the hypoxia response of the lev-11 gene in nematode, the death rate was compared among lev-11 (x12), daf-2, daf16 mutants and wild type worms. To the best of our knowledge, our results are the first to demonstrate that 


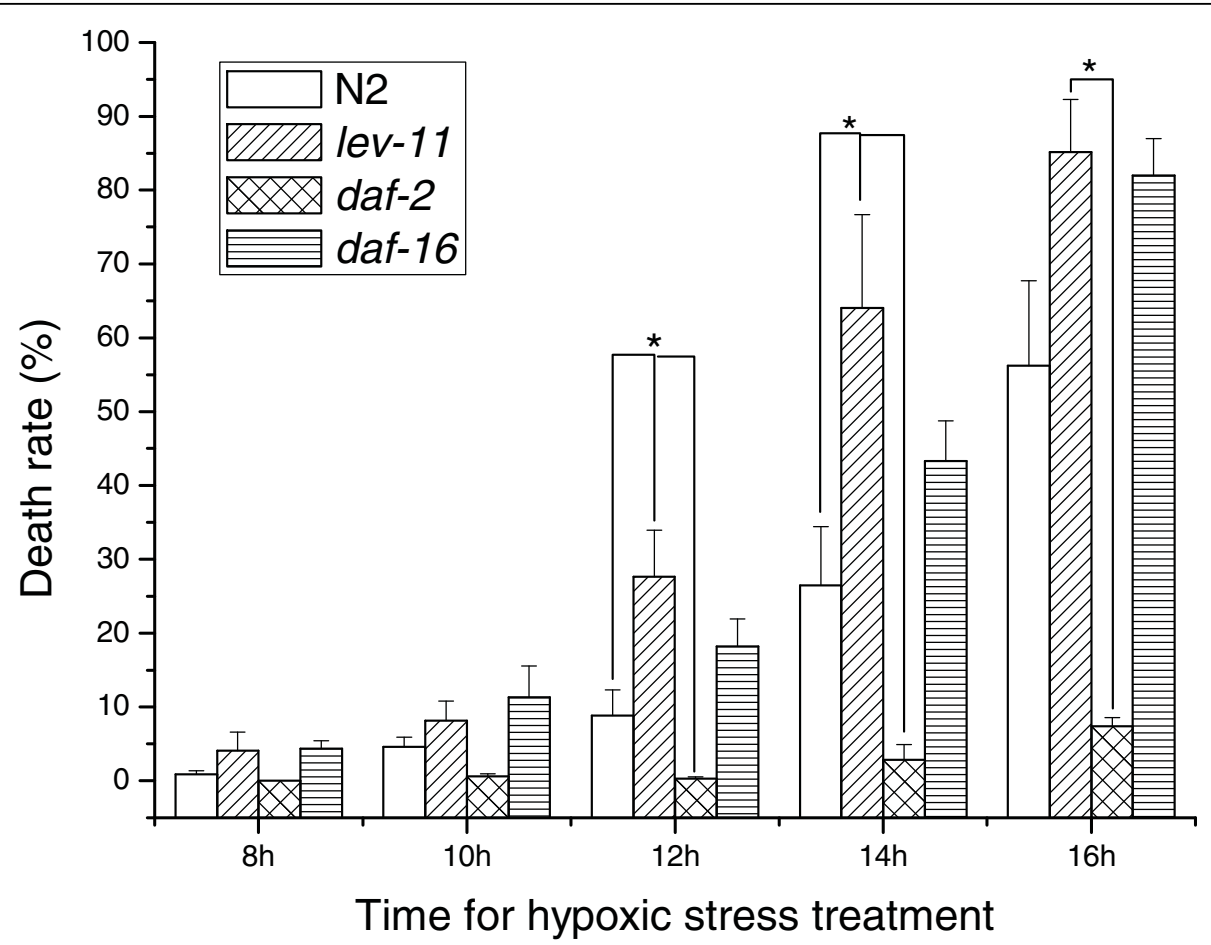

Figure 4 Death rate of the lev-11(x12), daf-2 (hypoxia-resistant) and daf-16 (hypoxia-sensitive) mutants and that of the wild type animals (N2) exposed to $8,10,12,14$ and $16 \mathrm{~h}$ of hypoxia ( $0.2 \%$ oxygen) and after a $24-\mathrm{h}$ recovery (21\% oxygen). The death rate of the wild type N2 strain and lev-11(x12) mutant gradually increased as the time under hypoxic conditions increased. The daf-2 mutants were highly resistant to hypoxia, whereas the daf-16 mutants were highly sensitive to hypoxia. The death rate was significantly different when the wild type animals $(8.85 \% \pm 3.50,26.44 \% \pm 7.96)$ were compared with the lev-11 (x12) strain $(27.64 \% \pm 6.30,64.06 \% \pm 12.00)$ after $12 \mathrm{~h}$ and $14 \mathrm{~h}$ of hypoxia treatment, respectively $(P=0.0183, P=0.0401)$. After $12 \mathrm{~h}$ of hypoxia, the death rate of the lev-11 ( $x 12)$ strain was higher than that of the daf-16 mutant. The results are displayed as means \pm standard deviation, $n>3, *: P<0.05$.

the lev-11 (x12) mutant displays a hypoxia-sensitive phenotype, which supports the idea that LEV-11 plays a role in the hypoxia response and survival in C. elegans.

Therefore, we hypothesized that these cytoskeletal changes have an important role in the early hypoxia response. We propose that the synthesis of structural proteins contributes to the maintenance of the shape and function of the nematodes. These proteins are believed to be responsible for helping the worms adjust to an oxygen-deprived environment.

\section{Proteins related to energy production}

The proteins ATP-2, ATP-5 and VHA-8 that were identified in this study are associated with energy and metabolism. Their altered expression levels are consistent with the altered energy metabolism seen under hypoxic conditions. ATP-2 encodes the beta subunit of the soluble catalytic F1 portion of ATP synthase (mitochondrial respiratory chain complex V) [52]. ATP-5 encodes subunit $\mathrm{d}$ of mitochondrial F1/F0-ATP synthase, and vha-8 encodes an ortholog of subunit $\mathrm{E}$ of the cytoplasmic (V1) domain of vacuolar proton-translocating ATPase (V-ATPase). These enzymes are involved in aerobic respiration, which is the most efficient metabolic energy pathway. Under normoxia, most energy is produced this way. As a result of the lack of oxygen after hypoxia treatment, the upregulation of these enzymes likely reflects severe energy deficits in these worms, and these enzymes would be quickly activated to produce energy under early hypoxic stress.

F46H5.3 encodes arginine kinase (AK), which is a member of the phosphagen (guanidino) kinase family of highly conserved enzymes that catalyze the reversible transfer of phosphate from a phosphorylated guanidine $\left(\sim \mathrm{NH}-\mathrm{CN}_{2} \mathrm{H}_{4}^{+}\right)$substrate to ADP to satisfy short-term ATP requirements [53]. AK has significant sequence similarity to creatine kinase and likely serves the same function in the muscle of $C$. elegans as creatine kinase does in mammalian cells [54]. AK isoform a was upregulated, while isoform b was downregulated. The upregulation of AK isoform a suggests an alternative method for the production of ATP to adapt to hypoxic conditions at an early stage. The substrate concentration decreased as the time of the hypoxia treatment increased, and this reaction was gradually reduced over time. 
Table 2 Gene ontology analysis of differently expressed proteins identified by MALDI-TOF/TOF MS

\begin{tabular}{|c|c|c|c|c|}
\hline GO ID & GO term & Number of proteins & Fold enrichment & $P$ value \\
\hline GO:0002119 & larval development & $\begin{array}{l}11 \text { (lev-11, rpl-8, rps-8, rpl-21, act-4, mlc-2, } \\
\text { rpl-7, hsp-1, atp-2, atp-5, mlc-1) }\end{array}$ & 3.71 & $5.60 \mathrm{E}-05$ \\
\hline GO:0002164 & larval development & $\begin{array}{l}11 \text { (lev-11, rpl-8, rps-8, rpl-21, act-4, mlc-2, } \\
\text { rpl-7, hsp-1, atp-2, atp-5, mlc-1) }\end{array}$ & 3.71 & 5.67E-05 \\
\hline GO:0015986 & ATP synthesis coupled proton transport & 3 (vha-8, atp-2, atp-5) & 31.33 & $3.50 \mathrm{E}-03$ \\
\hline GO:0046034 & ATP metabolic process & 3 (vha-8, atp-2, atp-5) & 29.37 & $3.98 \mathrm{E}-03$ \\
\hline GO:0006818 & hydrogen transport & 3 (vha-8, atp-2, atp-5) & 23.49 & $6.15 \mathrm{E}-03$ \\
\hline GO:0015992 & proton transport & 3 (vha-8, atp-2, atp-5) & 23.49 & $6.15 \mathrm{E}-03$ \\
\hline GO:0016820 & $\begin{array}{c}\text { hydrolase activity, acting on acid anhydrides, } \\
\text { catalyzing transmembrane movement of } \\
\text { substances }\end{array}$ & 3 (vha-8, atp-2, atp-5) & 13.50 & $1.68 \mathrm{E}-02$ \\
\hline GO:0015399 & primary active transmembrane transporter activity & 3 (vha-8, atp-2, atp-5) & 13.28 & $1.73 \mathrm{E}-02$ \\
\hline GO:0051188 & cofactor biosynthetic process & 3 (vha-8, atp-2, atp-5) & 12.59 & 2.04E-02 \\
\hline GO:0030554 & adenyl nucleotide binding & 6 (unc-89, act-4, hsp-1, atp-2, atp-5, ZK593.9) & 3.07 & $2.22 \mathrm{E}-02$ \\
\hline GO:0006732 & coenzyme metabolic process & 3 (vha-8, atp-2, atp-5) & 11.37 & $2.46 \mathrm{E}-02$ \\
\hline GO:0009165 & nucleotide biosynthetic process & 3 (vha-8, atp-2, atp-5) & 11.37 & 2.46E-02 \\
\hline GO:0032555 & purine ribonucleotide binding & $\begin{array}{c}6 \text { (unc-89ᄀ, act-4, hsp-1, atp-2, atp-5, } \\
\text { ZK593.9) }\end{array}$ & 2.79 & $3.26 \mathrm{E}-02$ \\
\hline GO:0045927 & positive regulation of growth & $\begin{array}{c}7 \text { (far-1, mlc-1, atp-2, atp-5, rpl-7, rpl-8, tag- } \\
173 \text { ) }\end{array}$ & 2.45 & $3.71 \mathrm{E}-02$ \\
\hline GO:0055086 & $\begin{array}{l}\text { nucleobase, nucleoside and nucleotide metabolic } \\
\text { process }\end{array}$ & 3 (vha-8, atp-2, atp-5) & 8.49 & $4.21 \mathrm{E}-02$ \\
\hline GO:0006796 & phosphate metabolic process & 5 (unc-89,ZK593.9, vha-8, atp-2, atp-5) & 3.31 & 4.61E-02 \\
\hline
\end{tabular}

Far-1 encodes the fatty acid and retinol binding protein, which may interfere with intercellular lipid signaling to manipulate the defense reactions of the host or to acquire essential lipids for the nematode [55]. Far-1 was upregulated after the hypoxia treatment, suggesting that an increase of FAR-1 could help the worms produce energy from lipids.

The proteins related to energy and metabolism and discussed here can also be induced by other stress conditions and appear to be important for survival during various stress conditions. Taken together, these observations suggest that energy is important for the maintenance of hypoxic relaxation. To maintain a balance of ATP demand and supply, various pathways should be activated to produce energy. In this study, however, the enzymes involved in anaerobic pathways were not upregulated, as has been seen in other studies $[25,56]$. This contrast may be related to the short duration of the hypoxic stress, and after long-term hypoxia exposure, glucose might become one of the main fuel sources.

\section{Ribosomal proteins}

Among the ten down-regulated proteins, four are the ribosomal proteins RPL-7, RPL-8, RPS-8, and RPL-21. RPL-7 and RPL-8 encode the large ribosomal subunit L7 protein that has been reported by mass RNAi assays to be required for embryonic viability and normal, rapid growth [57]. RPS-8 encodes the small ribosomal subunit S8 protein, which is predicted to function in protein biosynthesis. RPS- 8 activity is required for germline development and the overall health of C. elegans [58]. RPL-21 encodes the large ribosomal subunit L21 protein [59], involved in translation in the ribosomal machine. In our study, all four ribosomal proteins were downregulated at the protein level after hypoxia treatment, suggesting that protein synthesis was suppressed in C. elegans during hypoxia. The inhibition of protein synthesis and the conservation of energy is advantageous for hypoxic worms because a decreased translation rate will consequently reduce oxygen consumption. Reduced oxygen consumption by translational arrest has been reported to be a logical and established mechanism for the reduction of cellular injury during, but not after, hypoxia [60-62]. Anderson $e t$ al. also reported that $C$. elegans could survive hypoxia by the inactivation of aminoacyl-tRNA synthetases, enzymes essential for protein translation [63]. Consistent with a reduction in protein synthesis, our data suggest that the downregulation of these ribosomal proteins may contribute to a hypoxia-mediated global translation attenuation in C. elegans.

\section{Chaperones}

Heat shock proteins (HSP) have been reported to be induced by many types of stress. In fact, HSP70 and 
HSP90 family proteins are induced by hypoxia in various systems [64-67]. The HSP proteins are also chaperone proteins that can assist in the folding of proteins. Overexpression of individual molecular chaperones in C. elegans has been shown to extend the life span [68]. There are at least nine genes in the HSP70 family of C. elegans [69]. In this study, HSP-1, encoding heat shock $70 \mathrm{kDa}$ protein $\mathrm{A}$, was downregulated in response to short-term hypoxia. This observation suggests that the amount of newly synthesized protein could be partially reduced by increasing the amount of unfolded proteins.

\section{Other proteins}

After a short-term exposure to hypoxia, the protein F27D4.5 was upregulated, and the proteins ZK593.9 and Y54E5A.5 were downregulated, which was confirmed by transcript alterations. There are no clear descriptions of the molecular functions of these proteins to date. According to the GO term annotation, F27D4.5 is involved in the positive regulation of growth, and ZK593.9 is related to proteins involved in adenyl nucleotide binding, purine ribonucleotide binding, and the phosphate metabolic process. Further studies on these proteins may help understand their functions under hypoxic stress in C. elegans.

Reactive oxygen species (ROS) have been reported to be released during hypoxia, which may contribute to the stabilization of HIF-1 $\alpha[70,71]$. Some hypoxia-related proteins (e.g., globins, HIF-1, ROS), however, were not identified in this study either because their expression level was too low to be detected or there was no significant difference at this time point. The limitations of this approach should also be considered. In addition, none of the differentially expressed proteins had a connection to the HIF pathway. Although there may be a connection between HIF pathway and ATP production and consumption, more studies should be performed to confirm that the HIF pathway is not involved early response to hypoxia and to better understand the role of HIF-1 in the context of temporal expression.

A comparison between hypoxia-induced mRNAs and our proteomic results was performed, but no overlap was found. The low correlation between the levels of mRNA and protein, with the activity of the protein often controlled by various post-translational modifications instead, has become widely accepted [72,73]. Shen et al. found that some metabolic enzymes, such as PYC1, F14B4.2 hexokinase and R05F9.6 phospholglucomutase, were induced by hypoxia, which would induce the production of ATP [20]. In this study, the proteins ATP-2, ATP-5 and VHA-8, which are associated with energy and metabolism, had altered expression levels. Our results showed that three ribosomal proteins were downregulated during hypoxic stress. This observation is closely related to that reported by Mabon, who showed that the inhibition of many different translation machinery proteins can protect from hypoxic injury [17]. Therefore, there are similarities between our proteomic data and the mRNA expression data of others that might represent an interesting correlation.

Scott et al. showed that wild type C. elegans became immobile after exposure to a severe hypoxic environment $(<0.3 \%$ oxygen) but fully recovered when returned to normoxia within $4 \mathrm{~h}$ [14]. After $4 \mathrm{~h}$, however, permanent behavioral deficits and cellular death ensue, and after a 22-h hypoxic incubation, $>99 \%$ of wild type animals are dead. These deaths are not the result of programmed cell death [74]. In most tissues during ischemia-reperfusion, an initial response has been observed within the first hours $(0-4 \mathrm{~h})$, followed by a late response that occurred after approximately $12-24 \mathrm{~h}$ $[75,76]$. Based on these data, the length of hypoxia exposure was selected as $4 \mathrm{~h}$. In addition, L4 stage worms were used because they did not carry embryos yet. Worms that contain eggs might be particularly vulnerable to hypoxic injury and thereby alter the hypoxic sensitivity of the whole organism. The last larval stage is suitable for investigating the effects of hypoxia on the protein expression level of only that generation. The C. elegans experiments were usually performed between $15-25^{\circ} \mathrm{C}$. Dasgupta et al. reported that hypoxia at temperature higher than the normal physiological temperature can still induce a protective response [77], therefore the temperature for hypoxia stress was selected as $26^{\circ} \mathrm{C}$ in our experiment. This study represents the first proteomic analysis to investigate the altered proteins during a 4-h exposure to hypoxia in L4 stage wild type C. elegans at $26^{\circ} \mathrm{C}$ compared with a control group exposed to normoxic conditions.

The use of animal model systems is widely accepted as being important to understand the response to oxygen deprivation, which is involved in many human health issues, such as cancer, stroke, and cardiac failure. Given that the objective of this study was to gain a better understanding of oxygen-deprivation response and survival mechanisms, our data have provided a proteomic landscape of the molecular response to short-term hypoxia exposure in C. elegans. The reorganization of cytoskeletal structural proteins is important for adaptation to hypoxic conditions. The preservation of the cytoskeleton and shape of cells in the presence of hypoxia would allow the worms to maintain its vital need to exchange oxygen. The synthesis of several proteins is important to maintain cell function and integrity. On the other hand, we present new evidence that translation arrest during hypoxia is induced by a downregulation of ribosomal proteins in C. elegans. This 
observation will help to understand the mechanisms involved in hypoxia adaptation better. Given the evolutionarily conserved functions in C. elegans (including humans), these data will broaden our understanding of how cellular remodeling might occur during hypoxia and also provide new insights into the hypoxia stress response and survival of $C$. elegans at the protein level. Worm cells appear to cope well during early stage hypoxia. Studies on the protein expression profiles in response to different times of hypoxia exposure will be interesting, and the resulting data obtained in C. elegans might be applicable to mammalian cells.

\section{Conclusions}

Taken together, our data suggest that altered protein expression, structural protein remodeling, and the reduction of translation might play important roles in the early response to oxygen deprivation in C. elegans, and this information will help broaden our knowledge on the mechanism of hypoxia response.

\section{Methods}

Synchronized culture and hypoxic treatment of $C$. elegans The wild type strain N2 (obtained from CGC) of C. elegans was cultured at $20^{\circ} \mathrm{C}$ on $9-\mathrm{cm}$ nematode growth medium agar plates seeded with E. coli OP50 as described by Brenner [78]. After washing off the adult worms with M9 buffer $\left(3 \mathrm{~g} / \mathrm{l} \mathrm{KH}_{2} \mathrm{PO}_{4}, 6 \mathrm{~g} / \mathrm{l} \mathrm{Na} \mathrm{HPO}_{4}\right.$, $5 \mathrm{~g} / \mathrm{l} \mathrm{NaCl}, 10 \mathrm{mM} \mathrm{MgSO}_{4}$ ) from the plates, embryos were obtained by dissolving gravid animals with alkaline hypochlorite $(0.25 \mathrm{M} \mathrm{NaOH}, 1.2 \% \mathrm{NaOCl})$. Briefly, the pellet of worms $(\sim 0.5 \mathrm{ml})$ was resuspended and dissolved in $5 \mathrm{ml}$ of an alkaline hypochlorite solution with frequent agitation. After centrifugation, the embryos that were released from the worms were washed twice with M9 buffer to remove the carcasses and then incubated at $20^{\circ} \mathrm{C}$ for a further $16 \mathrm{~h}$ to allow hatching. These worms have six development stages: embryo, L1-L4 larvae, and adult. Newly hatched L1 larvae were collected, seeded on fresh plates and incubated to the L4 larval stage. The L4 stage was selected for this study because it cannot carry embryos yet. The synchronized, cultured L4 worms were quickly harvested into a tube with M9 buffer and washed three times. The hypoxia group was incubated for $4 \mathrm{~h}$ in a sealed hypoxia chamber with a constant gas flow $\left(95 \% \mathrm{~N}_{2}, 5 \% \mathrm{CO}_{2}\right)$ at $26^{\circ} \mathrm{C}$, and the oxygen level set to $0.2 \%$, which was monitored by an oxygen probe. The control group was incubated for $4 \mathrm{~h}$ in a sealed chamber with a constant gas flow $\left(95 \% \mathrm{~N}_{2}, 5 \% \mathrm{CO}_{2}\right)$ at $26^{\circ} \mathrm{C}$ and the oxygen level set to normal levels $\left(21 \% \mathrm{O}_{2}\right)$. After the 4 -h incubation, the worms were removed from the chambers and stored in liquid nitrogen before use.

\section{Sample preparation}

After washing with M9 buffer and distilled water, the worms were resuspended in an equal volume of lysis buffer (7 M urea, $2 \mathrm{M}$ thiourea, $4 \% \mathrm{w} / \mathrm{v}$ CHAPS, $30 \mathrm{mM}$ Tris- $\mathrm{HCl}, \mathrm{pH}$ 8.5) with a protease inhibitor cocktail, frozen in liquid nitrogen, and then ground into powder with a chilled mortar and pestle. The homogenates were sonicated on ice briefly and then centrifuged at 13,000 $\mathrm{rpm}$ for $30 \mathrm{~min}$ at $4^{\circ} \mathrm{C}$. The supernatants were removed and used as the protein samples. Protein samples were extracted from the nematodes at least eight times, and the extracted were mixed together. Protein concentrations were determined using the 2D Quant Kit (GE Healthcare) according to the manufacturer's protocol. The samples were stored at $-80^{\circ} \mathrm{C}$ until use.

\section{Two-dimensional difference gel electrophoresis (2D-DIGE)}

The $\mathrm{pH}$ of each protein sample was adjusted to 8.5 with $50 \mathrm{mM} \mathrm{NaOH}$, and the final concentration was adjusted to $5 \mathrm{mg} / \mathrm{ml}$ with lysis buffer. Equal amounts of protein from the sample pairs were pooled together as an internal standard. The hypoxia-treated and control samples were randomly labeled with $\mathrm{Cy} 3$ or $\mathrm{Cy} 5$, whereas the internal standards were labeled with $\mathrm{Cy} 2$ using $400 \mathrm{pmol}$ of fluorochrome $/ 50 \mu \mathrm{g}$ of protein (GE Healthcare). Labeling was performed for $30 \mathrm{~min}$ on ice in the dark. The reactions were terminated by adding $1 \mu \mathrm{l}$ of $10 \mathrm{mM}$ lysine for $10 \mathrm{~min}$ on ice in the dark.

After $50 \mu \mathrm{g}$ each of the Cy3- and Cy5-labeled samples were combined, they were then mixed with $50 \mu \mathrm{g}$ of the Cy2-labeled internal standard. An equal volume of $2 \times$ sample buffer (7 M urea, $2 \mathrm{M}$ thiourea, 4\% CHAPS, 1\% Bio-Lyte, $\mathrm{pH} 3-10,20 \mathrm{mg} / \mathrm{ml}$ DTT) was added to the sample, and the total volume was increased to $410 \mu \mathrm{l}$ with rehydration buffer (7 M urea, $2 \mathrm{M}$ thiourea, $4 \%$ CHAPS, $0.5 \%$ Bio-Lyte, $10 \mathrm{mg} / \mathrm{ml}$ DTT). The samples were actively rehydrated into $18-\mathrm{cm}$ pH 3-10 IPG strips at $17^{\circ} \mathrm{C}$ for $12 \mathrm{~h}$ using an $\mathrm{Ettan}^{\mathrm{mm}}$ IPGphor IEF System (GE Healthcare). Isoelectric focusing was performed for a total of $80 \mathrm{kV}-\mathrm{h}$ (ramped to $250 \mathrm{~V}$ in $30 \mathrm{~min}$, held at $1000 \mathrm{~V}$ for $1 \mathrm{~h}$, ramped to $10,000 \mathrm{~V}$ in $5 \mathrm{~h}$, and held at $10,000 \mathrm{~V}$ for $60 \mathrm{kV}-\mathrm{h}$ ). The IPG strips were equilibrated in equilibration buffer ( $6 \mathrm{M}$ urea, $2 \%$ SDS, $50 \mathrm{mM}$ Tris$\mathrm{HCl}, \mathrm{pH} 8.8,30 \%$ glycerol) supplemented with $0.5 \%$ DTT for $15 \mathrm{~min}$ at room temperature, followed with $4.5 \%$ iodoacetamide in equilibration buffer for another 15-min incubation at room temperature.

The IPG strips were placed on the top of a $12 \%$ homogeneous polyacrylamide gel that had been precast with low fluorescence glass plates using an Ettan DALT twelve gel caster. The second dimension SDS-PAGE was carried out using the Ettan DALT II (GE Healthcare). After two-dimensional electrophoresis (2DE), the gels 
were scanned on the Typhoon 9410 scanner with Ettan DALT gel alignment guides using excitation/emission wavelengths specific for Cy2 $(488 / 520 \mathrm{~nm})$, Cy3 (532/ $580 \mathrm{~nm})$, and Cy5 $(633 / 670 \mathrm{~nm})$. The intensity was adjusted to ensure that the maximum volume of each image was within 60,000-90,000.

The gel-to-gel spot matching and statistical analyses of the protein abundances among the samples were carried out with the DeCyder 5.0 BVA (biological variation analysis, GE Healthcare) according to the manufacturer's protocol. Statistically significant differences were calculated by a paired Student's $t$-test, and the significance level was set at $P<0.05$. Protein spots that were differentially expressed in the hypoxia-treated and control groups $\left(\mathrm{ratio}_{\text {hypoxia/control }} \geq 1.5\right.$ or $\mathrm{ratio}_{\text {hypoxia/control }} \leq$ $-1.5, P<0.05)$ were marked.

During our studies, we ran three gels for each DIGE analysis on one batch of $C$. elegans, and we totally used three batches of C. elegans as independent experiments to meet the standard for biological replicates. Therefore, three biological replicated were included in our analyses to guarantee the statistical analysis for the samples, and the statistical values were averaged from multiple independent experiments.

\section{Protein identification by MALDI-TOF-TOF-MS}

For protein identification, preparative gels were loaded with 500-1000 $\mu \mathrm{g}$ of unlabeled sample. The electrophoretic conditions were the same as for the 2D-DIGE. After staining with Coomassie Brilliant Blue, the protein spots of interest were excised and destained with a solution of $25 \mathrm{mM}$ ammonium bicarbonate and 50\% ACN. The gels were then dried completely by centrifugal lyophilization. An in-gel digestion was performed with $0.01 \mu \mathrm{g} / \mu \mathrm{l}$ tryp$\sin$ (Promega) in $25 \mathrm{mM}$ ammonium bicarbonate for 15 $\mathrm{h}$ at $37^{\circ} \mathrm{C}$. The supernatants were collected, and the tryptic peptides were extracted from the gel sequentially with $5 \%$ TFA at $40^{\circ} \mathrm{C}$ for $1 \mathrm{~h}$ and with a solution of $2.5 \%$ TFA and $50 \% \mathrm{ACN}$ at $30^{\circ} \mathrm{C}$ for $1 \mathrm{~h}$. The extracts were pooled and dried completely by centrifugal lyophilization.

The peptide mixtures were redissolved in $0.5 \%$ TFA, and $1 \mu \mathrm{l}$ of the peptide solution was mixed with $1 \mu \mathrm{l}$ of matrix (4-hydroxy- $\alpha$-cyanocinnamic acid in $30 \% \mathrm{ACN}$ and $0.1 \%$ TFA) before spotting on the target plate. MALDI-TOF mass spectrometry and tandem TOF/TOF mass spectrometry were performed on a ABI-4800 Proteomics Analyzer. Peptide mass maps were acquired in positive reflection mode, averaging 1500 laser shots per MALDI-TOF spectrum and 3000 shots per TOF/TOF spectrum with a resolution of 20,000. The 4800 calibration mixtures were used to calibrate the spectrum to a mass tolerance within $0.1 \mathrm{Da}$. Parent mass peaks with a mass range of 600-4000 $\mathrm{Da}$ and minimum signal-tonoise ratio of 15 were selected for tandem TOF/TOF analysis. The combined mass and mass/mass spectra were used to interrogate $C$. elegans sequences in the Swiss-Prot database using the MASCOT database search algorithms, allowing for carbamidomethylation, oxidation, and a maximum of one missed trypsin cleavage. The peptide and MS/MS tolerances were both $0.2 \mathrm{Da}$. All of the automatic data analysis and database searches were performed by the GPS Explorer ${ }^{\mathrm{Tm}}$ software (version 3.6, Applied Biosystems). Known contaminant ions (such as keratin) were excluded. A confident identification had a statistically significant $(P<0.05)$ protein score (based on combined mass and mass/mass spectra) and a best ion score (based on mass/mass spectra).

\section{Western blot}

Proteins from the hypoxia-treated C. elegans and control animals were separated on $12 \%$ polyacrylamide gels and transferred to PVDF membranes (Amersham Biosciences). These blots were incubated for $2 \mathrm{~h}$ at room temperature in Tris-buffered-saline with Tween $(20 \mathrm{mM}$ Tris-Cl, $140 \mathrm{mM} \mathrm{NaCl}$, pH 7.5, 0.05\% Tween 20) containing 5\% skim milk. The blots were incubated with an anti-tropomyosin monoclonal antibody (working dilution 1:1000, Sigma-Aldrich) overnight at $4^{\circ} \mathrm{C}$. After washing three times in Tris-buffered-saline with Tween, the blots were incubated with a horseradish peroxidase-conjugated secondary antibody (working dilution 1:5000, Beijing Zhong-Shan Biotechnology) for $1 \mathrm{~h}$ at room temperature. Immunoreactive complexes were visualized using ECL reagents (GE Healthcare). The housekeeping protein $\alpha-$ tubulin was used as an internal control (monoclonal antibody, working dilution 1:400, Wuhan Boshide Biotechnology). Protein expression levels were quantified with the ImageJ software. The data was statistically analyzed by OriginPro v8.0 software using a paired Student's $t$-test, with $P<0.05$ indicating a significant difference.

\section{Analysis of death rate after hypoxia}

The lev-11, daf-2 (hypoxia-resistant), daf-16 (hypoxiasensitive) mutant strains were kindly provided by the CGC and cultured as described above. Approximately 100 to $150 \mathrm{~L} 4$ larvae from each of the three mutant strains and the wild type (N2) were quickly harvested in a tube with M9 buffer, washed three times, and incubated for $8 \mathrm{~h}, 10 \mathrm{~h}, 12 \mathrm{~h}, 14 \mathrm{~h}$ and $16 \mathrm{~h}$ in a sealed hypoxia chamber $\left(0.2 \%\right.$ oxygen, $\left.26^{\circ} \mathrm{C}\right)$. The worms were then cultured at normoxia $\left(21 \%\right.$ oxygen, $\left.20^{\circ} \mathrm{C}\right)$ on $3-\mathrm{cm}$ nematode growth medium agar plates seeded with E. coli OP50. After $24 \mathrm{~h}$, the numbers of living and dead worms were counted, which were used to calculate the 
death rate. Worms without spontaneous or touchevoked movement were scored as dead. The experiments were repeated at least three times $(n>3)$. The statistical analysis was performed by OriginPro v8.0 software using a paired Student's $t$-test, with $P<0.05$ indicating a significant difference.

\section{Gene Ontology (GO) Analysis}

Searches for the gene ontology (GO) classifications of the proteins identified by MALDI/TOF/TOF were performed using the web-accessible DAVID annotation system http://david.abcc.ncifcrf.gov/.

\section{Acknowledgements}

The C. elegans wild type strain (N2) and lev-11 mutant were obtained from the Caenorhabditis Genetics Center, which is supported by the National Institutes of Health National Center for Research Resources. This work is supported by National Basic Research Project (973 program) (2006CB504100), The National Key Technologies R\&D Program for New Drugs (2009ZX09103616, 2009ZX09503-002, 2009ZX09301-002), General Program (30900862, $30800196,30772293,30701045$ ) of General Program of National Natural Science Foundation of China, Major Program for Science and Technology Research of Beijing Municipal Bureau (7061004).

\section{Author details}

'Life Science College of Nanjing Agriculture University, Nanjing 210095, China. ${ }^{2}$ Beijing Institute of Radiation Medicine, State Key Laboratory of Proteomics, Beijing 100850, China. ${ }^{3}$ Medical College of Yangzhou University, Yangzhou 225001, China. ${ }^{4}$ Department of Health Statistics, School of Military Preventive Medicine, Fourth Military Medical University, Xi'an 710032, China.

\section{Authors' contributions}

$\mathrm{HL}$ wrote the main manuscript and did the most of the experiments. CR and IS helped on the C. elegans models for this study and completed the additional studies for revising the manuscript. $\mathrm{XH}$ helped on the bioinformatic analysis. FZ, YG and YW helped on the Western blot analysis. LX and CC gave English writing suggestions and statistical analyses on this work. CZ designed and supervised the study, finalized the manuscript. All authors read and approved the manuscript.

\section{Competing interests}

The authors declare that they have no competing interests.

Received: 9 April 2010 Accepted: 21 September 2010 Published: 21 September 2010

\section{References}

1. Semenza GL: Hypoxia-inducible factor 1: oxygen homeostasis and disease pathophysiology. Trends Mol Med 2001, 7:345-350.

2. Wenger RH: Cellular adaptation to hypoxia: O2-sensing protein hydroxylases, hypoxia-inducible transcription factors, and O2-regulated gene expression. Faseb J 2002, 16:1151-1162.

3. Ren CH, Zhang CG: [Caenorhabditis elegans: a good model for hypoxia response research]. Sheng Li Ke Xue Jin Zhan 2008, 39:84-87.

4. Brett D, Pospisil H, Valcarcel J, Reich J, Bork P: Alternative splicing and genome complexity. Nat Genet 2002, 30:29-30.

5. Padilla PA, Nystul TG, Zager RA, Johnson AC, Roth MB: Dephosphorylation of cell cycle-regulated proteins correlates with anoxia-induced suspended animation in Caenorhabditis elegans. Mol Biol Cell 2002, 13:1473-1483.

6. Hajeri VA, Trejo J, Padilla PA: Characterization of sub-nuclear changes in Caenorhabditis elegans embryos exposed to brief, intermediate and long-term anoxia to analyze anoxia-induced cell cycle arrest. BMC Cell Biol 2005, 6:47.

7. Van Voorhies WA, Ward S: Broad oxygen tolerance in the nematode Caenorhabditis elegans. J Exp Biol 2000, 203:2467-2478.
8. Epstein AC, Gleadle JM, MCNeill LA, Hewitson KS, O'Rourke J, Mole DR, Mukherji M, Metzen E, Wilson Ml, Dhanda A, et al: C. elegans EGL-9 and mammalian homologs define a family of dioxygenases that regulate HIF by prolyl hydroxylation. Cell 2001, 107:43-54.

9. Jiang H, Guo R, Powell-Coffman JA: The Caenorhabditis elegans hif-1 gene encodes a bHLH-PAS protein that is required for adaptation to hypoxia. Proc Natl Acad Sci USA 2001, 98:7916-7921.

10. Kloek AP, Sherman DR, Goldberg DE: Novel gene structure and evolutionary context of Caenorhabditis elegans globin. Gene 1993, 129:215-221.

11. Mansell JB, Timms K, Tate WP, Moens L, Trotman CN: Expression of a globin gene in Caenorhabditis elegans. Biochem Mol Biol Int 1993, 30:643-647.

12. Hoogewijs D, Geuens E, Dewilde S, Moens L, Vierstraete A, Vinogradov S, Vanfleteren J: Genome-wide analysis of the globin gene family of C. elegans. IUBMB Life 2004, 56:697-702.

13. Hoogewijs D, Geuens E, Dewilde S, Vierstraete A, Moens L, Vinogradov S, Vanfleteren JR: Wide diversity in structure and expression profiles among members of the Caenorhabditis elegans globin protein family. BMC Genomics 2007, 8:356.

14. Scott BA, Avidan MS, Crowder CM: Regulation of hypoxic death in C. elegans by the insulin/IGF receptor homolog DAF-2. Science 2002, 296:2388-2391.

15. Link CD, Taft A, Kapulkin V, Duke K, Kim S, Fei Q, Wood DE, Sahagan BG Gene expression analysis in a transgenic Caenorhabditis elegans Alzheimer's disease model. Neurobiol Aging 2003, 24:397-413.

16. Chang AJ, Bargmann Cl: Hypoxia and the HIF-1 transcriptional pathway reorganize a neuronal circuit for oxygen-dependent behavior in Caenorhabditis elegans. Proc Natl Acad Sci USA 2008, 105:7321-7326.

17. Mabon ME, Mao X, Jiao Y, Scott BA, Crowder CM: Systematic identification of gene activities promoting hypoxic death. Genetics 2009, 181:483-496.

18. Hamilton B, Dong Y, Shindo M, Liu W, Odell I, Ruvkun G, Lee SS: A systematic RNAi screen for longevity genes in C. elegans. Genes Dev 2005, 19:1544-1555.

19. Hong M, Kwon JY, Shim J, Lee J: Differential hypoxia response of hsp-16 genes in the nematode. J Mol Biol 2004, 344:369-381.

20. Shen C, Nettleton D, Jiang M, Kim SK, Powell-Coffman JA: Roles of the HIF-1 hypoxia-inducible factor during hypoxia response in Caenorhabditis elegans. J Biol Chem 2005, 280:20580-20588.

21. Pandey A, Mann M: Proteomics to study genes and genomes. Nature 2000, 405:837-846

22. Kumar GK, Klein JB: Analysis of expression and posttranslational modification of proteins during hypoxia. J Appl Physiol 2004, 96:1178-1186, discussion 1170-1172.

23. Vorum H, Ostergaard M, Hensechke P, Enghild JJ, Riazati M, Rice GE: Proteomic analysis of hyperoxia-induced responses in the human choriocarcinoma cell line JEG-3. Proteomics 2004, 4:861-867.

24. Bosworth CAt, Chou CW, Cole RB, Rees BB: Protein expression patterns in zebrafish skeletal muscle: initial characterization and the effects of hypoxic exposure. Proteomics 2005, 5:1362-1371.

25. Wulff $T$, Jessen $F$, Roepstorff $P$, Hoffmann EK: Long term anoxia in rainbow trout investigated by 2-DE and MS/MS. Proteomics 2008, 8:1009-1018.

26. Jiang H, Li F, Xie Y, Huang B, Zhang J, Zhang J, Zhang C, Li S, Xiang J: Comparative proteomic profiles of the hepatopancreas in Fenneropenaeus chinensis response to hypoxic stress. Proteomics 2009, 9:3353-3367.

27. Audhya A, Desai A: Proteomics in Caenorhabditis elegans. Brief Funct Genomic Proteomic 2008, 7:205-210

28. Madi A, Mikkat S, Ringel B, Thiesen HJ, Glocker MO: Profiling stagedependent changes of protein expression in Caenorhabditis elegans by mass spectrometric proteome analysis leads to the identification of stage-specific marker proteins. Electrophoresis 2003, 24:1809-1817.

29. Madi A, Mikkat S, Ringel B, Ulbrich M, Thiesen HJ, Glocker MO: Mass spectrometric proteome analysis for profiling temperature-dependent changes of protein expression in wild-type Caenorhabditis elegans. Proteomics 2003, 3:1526-1534

30. Mawuenyega KG, Kaji H, Yamuchi Y, Shinkawa T, Saito H, Taoka M, Takahashi N, Isobe T: Large-scale identification of Caenorhabditis elegans proteins by multidimensional liquid chromatography-tandem mass spectrometry. J Proteome Res 2003, 2:23-35. 
31. Unlu M, Morgan ME, Minden JS: Difference gel electrophoresis: a single gel method for detecting changes in protein extracts. Electrophoresis 1997, 18:2071-2077.

32. Alban A, David SO, Bjorkesten L, Andersson C, Sloge E, Lewis S, Currie I: A novel experimental design for comparative two-dimensional gel analysis: two-dimensional difference gel electrophoresis incorporating a pooled internal standard. Proteomics 2003, 3:36-44.

33. Yan JX, Devenish AT, Wait R, Stone T, Lewis S, Fowler S: Fluorescence twodimensional difference gel electrophoresis and mass spectrometry based proteomic analysis of Escherichia coli. Proteomics 2002, 2:1682-1698.

34. Hu Y, Wang G, Chen GY, Fu X, Yao SQ: Proteome analysis of Saccharomyces cerevisiae under metal stress by two-dimensional differential gel electrophoresis. Electrophoresis 2003, 24:1458-1470.

35. Ruepp SU, Tonge RP, Shaw J, Wallis N, Pognan F: Genomics and proteomics analysis of acetaminophen toxicity in mouse liver. Toxicol Sci 2002, 65:135-150.

36. Sun W, Xing B, Sun Y, Du X, Lu M, Hao C, Lu Z, Mi W, Wu S, Wei H, et al: Proteome analysis of hepatocellular carcinoma by two-dimensional difference gel electrophoresis: novel protein markers in hepatocellular carcinoma tissues. Mol Cell Proteomics 2007, 6:1798-1808.

37. Tabuse $Y$, Nabetani T, Tsugita A: Proteomic analysis of protein expression profiles during Caenorhabditis elegans development using twodimensional difference gel electrophoresis. Proteomics 2005, 5:2876-2891.

38. Genome sequence of the nematode $C$. elegans: a platform for investigating biology. Science 1998, 282:2012-2018.

39. Yan D, Wu Z, Chisholm AD, Jin Y: The DLK-1 kinase promotes mRNA stability and local translation in C. elegans synapses and axon regeneration. Cell 2009, 138:1005-1018.

40. Schouest K, Zitova A, Spillane C, Papkovsky D: Toxicological assessment of chemicals using Caenorhabditis elegans and optical oxygen respirometry. Environ Toxicol Chem 2009, 28:791-799.

41. Krause M, Wild M, Rosenzweig B, Hirsh D: Wild-type and mutant actin genes in Caenorhabditis elegans. J Mol Biol 1989, 208:381-392

42. Aoshima D, Murata T, Hori M, Ozaki H: Time-dependent phenotypic and contractile changes of pulmonary artery in chronic hypoxia-induced pulmonary hypertension. J Pharmacol Sci 2009, 110:182-190.

43. Ostergaard L, Simonsen U, Eskildsen-Helmond Y, Vorum H, Uldbjerg N, Honore B, Mulvany MJ: Proteomics reveals lowering oxygen alters cytoskeletal and endoplasmatic stress proteins in human endothelial cells. Proteomics 2009, 9:4457-4467.

44. Cummins C, Anderson P: Regulatory myosin light-chain genes of Caenorhabditis elegans. Mol Cell Biol 1988, 8:5339-5349.

45. Rushforth AM, White CC, Anderson P: Functions of the Caenorhabditis elegans regulatory myosin light chain genes mlc- 1 and mlc-2. Genetics 1998, 150:1067-1077.

46. Benian GM, Tinley TL, Tang $X$, Borodovsky M: The Caenorhabditis elegans gene unc-89, required fpr muscle $M$-line assembly, encodes a giant modular protein composed of $\mathrm{lg}$ and signal transduction domains. J Cell Biol 1996, 132:835-848

47. Vibert PJ, Haselgrove JC, Lowy J, Poulsen FR: Structural changes in actincontaining filaments of muscle. J Mol Biol 1972, 71:757-767.

48. Marston S, Burton D, Copeland O, Fraser I, Gao Y, Hodgkinson J, Huber P, Levine B, el-Mezgueldi M, Notarianni G: Structural interactions between actin, tropomyosin, caldesmon and calcium binding protein and the regulation of smooth muscle thin filaments. Acta Physiol Scand 1998, 164:401-414

49. Rao UJ, Denslow ND, Block ER: Hypoxia induces the synthesis of tropomyosin in cultured porcine pulmonary artery endothelial cells. Am J Physiol 1994, 267:L271-281.

50. Kagawa $H$, Takuwa $K$, Sakube $Y$ : Mutations and expressions of the tropomyosin gene and the troponin $C$ gene of Caenorhabditis elegans. Cell Struct Funct 1997, 22:213-218.

51. Williams BD, Waterston RH: Genes critical for muscle development and function in Caenorhabditis elegans identified through lethal mutations. J Cell Biol 1994, 124:475-490.

52. Tsang WY, Sayles LC, Grad LI, Pilgrim DB, Lemire BD: Mitochondrial respiratory chain deficiency in Caenorhabditis elegans results in developmental arrest and increased life span. J Biol Chem 2001, 276:32240-32246.
53. Azzi A, Clark SA, Ellington WR, Chapman MS: The role of phosphagen specificity loops in arginine kinase. Protein Sci 2004, 13:575-585.

54. Suzuki T, Kamidochi M, Inoue N, Kawamichi H, Yazawa Y, Furukohri T, Ellington WR: Arginine kinase evolved twice: evidence that echinoderm arginine kinase originated from creatine kinase. Biochem J 1999, 340(Pt 3):671-675

55. Garofalo A, Rowlinson MC, Amambua NA, Hughes JM, Kelly SM, Price NC, Cooper A, Watson DG, Kennedy MW, Bradley JE: The FAR protein family of the nematode Caenorhabditis elegans. Differential lipid binding properties, structural characteristics, and developmental regulation. J Biol Chem 2003, 278:8065-8074.

56. Jackson DC: Living without oxygen: lessons from the freshwater turtle. Comp Biochem Physiol A Mol Integr Physiol 2000, 125:299-315.

57. Fraser AG, Kamath RS, Zipperlen P, Martinez-Campos M, Sohrmann M, Ahringer J: Functional genomic analysis of $C$. elegans chromosome I by systematic RNA interference. Nature 2000, 408:325-330.

58. Kamath RS, Fraser AG, Dong Y, Poulin G, Durbin R, Gotta M, Kanapin A, Le Bot N, Moreno S, Sohrmann M, et al: Systematic functional analysis of the Caenorhabditis elegans genome using RNAi. Nature 2003, 421:231-237.

59. Gonczy P, Echeverri C, Oegema K, Coulson A, Jones SJ, Copley RR, Duperon J, Oegema J, Brehm M, Cassin E, et al: Functional genomic analysis of cell division in C. elegans using RNAi of genes on chromosome III. Nature 2000, 408:331-336.

60. Paschen W, Proud CG, Mies G: Shut-down of translation, a global neuronal stress response: mechanisms and pathological relevance. Curr Pharm Des 2007, 13:1887-1902.

61. Wouters BG, van den Beucken T, Magagnin MG, Koritzinsky M, Fels D, Koumenis $C$ : Control of the hypoxic response through regulation of mRNA translation. Semin Cell Dev Biol 2005, 16:487-501.

62. DeGracia DJ, Kumar R, Owen CR, Krause GS, White BC: Molecular pathways of protein synthesis inhibition during brain reperfusion: implications for neuronal survival or death. J Cereb Blood Flow Metab 2002, 22:127-141.

63. Anderson LL, Mao X, Scott BA, Crowder CM: Survival from hypoxia in C. elegans by inactivation of aminoacyl-tRNA synthetases. Science 2009 323:630-633.

64. Hammerer-Lercher A, Mair J, Bonatti J, Watzka SB, Puschendorf B, Dirnhofer S: Hypoxia induces heat shock protein expression in human coronary artery bypass grafts. Cardiovasc Res 2001, 50:115-124.

65. Almgren CM, Olson LE: Moderate hypoxia increases heat shock protein 90 expression in excised rat aorta. J Vasc Res 1999, 36:363-371.

66. Ma E, Haddad GG: Anoxia regulates gene expression in the central nervous system of Drosophila melanogaster. Brain Res Mol Brain Res 1997, 46:325-328.

67. Patel B, Khaliq A, Jarvis-Evans J, Boulton M, Arrol S, Mackness M, McLeod D: Hypoxia induces HSP 70 gene expression in human hepatoma (HEP G2) cells. Biochem Mol Biol Int 1995, 36:907-912.

68. Yokoyama K, Fukumoto K, Murakami T, Harada S, Hosono R, Wadhwa R, Mitsui Y, Ohkuma S: Extended longevity of Caenorhabditis elegans by knocking in extra copies of hsp70F, a homolog of mot-2 (mortalin)/ mthsp70/Grp75. FEBS Lett 2002, 516:53-57.

69. Heschl MF, Baillie DL: The HSP70 multigene family of Caenorhabditis elegans. Comp Biochem Physiol B 1990, 96:633-637.

70. Chandel NS, McClintock DS, Feliciano CE, Wood TM, Melendez JA, Rodriguez AM, Schumacker PT: Reactive oxygen species generated at mitochondrial complex III stabilize hypoxia-inducible factor-1alpha during hypoxia: a mechanism of O2 sensing. J Biol Chem 2000, 275:25130-25138.

71. Hoogeboom D, Burgering BM: Should I stay or should I go: beta-catenin decides under stress. Biochim Biophys Acta 2009, 1796:63-74.

72. Peng J, Elias JE, Thoreen CC, Licklider LJ, Gygi SP: Evaluation of multidimensional chromatography coupled with tandem mass spectrometry (LC/LC-MS/MS) for large-scale protein analysis: the yeast proteome. J Proteome Res 2003, 2:43-50.

73. Chen G, Gharib TG, Huang CC, Taylor JM, Misek DE, Kardia SL, Giordano TJ, lannettoni MD, Orringer MB, Hanash SM, Beer DG: Discordant protein and mRNA expression in lung adenocarcinomas. Mol Cell Proteomics 2002, 1:304-313

74. Kourtis N, Tavernarakis N: Non-developmentally programmed cell death in Caenorhabditis elegans. Semin Cancer Biol 2007, 17:122-133.

75. Baxter GF, Ferdinandy P: Delayed preconditioning of myocardium: current perspectives. Basic Res Cardiol 2001, 96:329-344. 
76. Yellon DM, Downey JM: Preconditioning the myocardium: from cellular physiology to clinical cardiology. Physiol Rev 2003, 83:1113-1151.

77. Dasgupta N, Patel AM, Scott BA, Crowder CM: Hypoxic preconditioning requires the apoptosis protein CED-4 in C. elegans. Curr Biol 2007, 17:1954-1959.

78. Brenner S: The genetics of Caenorhabditis elegans. Genetics 1974, 77:71-94.

doi:10.1186/1477-5956-8-49

Cite this article as: Li et al: A proteomic view of Caenorhabditis elegans caused by short-term hypoxic stress. Proteome Science 2010 8:49.

Submit your next manuscript to BioMed Central and take full advantage of:

- Convenient online submission

- Thorough peer review

- No space constraints or color figure charges

- Immediate publication on acceptance

- Inclusion in PubMed, CAS, Scopus and Google Scholar

- Research which is freely available for redistribution

Submit your manuscript at www.biomedcentral.com/submit
C Biomed Central 